\title{
Vanguardia en doble página. Intervenciones del invencionismo argentino en la revista Joaquim ${ }^{\mathrm{I}}$
}

\author{
[ Avant-garde on double lay-out. Argentine Invencionism's \\ Interventions in Joaquim Issue
}

\section{María Amalia García ${ }^{2}$}

RESUMO - La presente investigación estudia la intervención del grupo de artistas argentinos Asociación Arte Concreto-Invención en la revista Joaquim (I946-I948) de Curitiba. El objetivo de este trabajo apunta a rastrear el postulado internacionalista que involucró a los proyectos abstraccionistas argentinos y la recepción que dichas propuestas tuvieron en el ámbito brasileño. En esta línea, se busca comprender la articulación de estos nuevos proyectos con una trama regional preexistente y analizar quiebres y disputas con otros núcleos culturales argentino-brasileños. - PALABRAS CLAVE Vanguardia, Revista Joaquim, Asociación Arte Concreto-Invención, Abstraccionismo. - ABSTRACT This research studies the intervention of the group of Argentine artists Asociación Arte Concreto-Invención within the journal Joaquim (I946-I948) of Curitiba. The objective of this paper aims to trace the internationalist postulated involving Argentine abstractionist projects and the reception of these proposals in the Brazilian context. In this line, this paper try to understand the articulation of these new projects into a preexisting regional network and analyze breakdowns and disputes with other Argentine-Brazilian cultural ties. - KEYwords Avant-Garde, Joaquim Issue, Asociación Arte Concreto-Invención, Abstract Art.

Recebido em I3 de março de 2014

Aprovado em 25 de julho de 2014

GARCíA, Maria Amalia. Vanguardia en doble página. Intervenciones del invencionismo argentino en la revista Joaquim. Revista do Instituto de Estudos Brasileiros, Brasil, n. 6I, p. I59-I82, ago. 2015. DoI: http://dx.doi.org/Io.II606/issn.23I6-90IX.voi6IpI59-I82

I Quiero agradecer a Gênese Andrade, Patricia M. Artundo y Jorge Schwartz las indicaciones brindadas sobre archivos y documentos analizados en este texto. Este artículo revisa y amplía algunos temas presentados en El arte abstracto. Intercambios culturales entre Argentina y Brasil. Buenos Aires, Siglo XXI, $20 I I$.

2 CONICET/Facultad de Filosofía y Letras (UBA, Buenos Aires, Argentina). 
Desplegado a doble página en el número nueve de la revista Joaquim se presentaba el invencionismo argentino en Brasil. ${ }^{3}$ En la página doce de esta revista de Curitiba $\left(n^{0}\right.$ I:I946 - n 2I:I948) se publicaba el "Manifiesto Invencionista" de la Asociación Arte Concreto-Invención (AACI), uno de los grupos impulsores de las propuestas abstractas en el ámbito porteño. Allí se republicaba el artículo "Invencionismo", de Carlos Drummond de Andrade, que había aparecido por primera vez en I946 en Correio da Manhã..$^{4}$ Esta "doble página" es la clave para introducirse en una nueva trama de relaciones artístico-literarias entre argentinos y brasileños. ${ }^{5}$

Trascender y borrar las fronteras geopolíticas fue uno de los ejes del programa de los artistas invencionistas: imágenes autónomas inscriptas en el internacionalismo marxista imprimieron esta dimensión transnacional a sus proyectos. Las revistas y boletines - en tanto aparatos de soporte y circulación visual y textual cumplieron un rol clave en la tarea de diseminar las nuevas ideas; junto a los catálogos de las exposiciones, fueron los soportes privilegiados para el intercambio, la reproducción y circulación de textos e imágenes en distintas latitudes.

3 Se utiliza el término "invencionismo" como concepto unificador de distintas propuestas no figurativas que tienen desarrollo en la Argentina durante los años I940 y I950. Asimismo, términos como "arte abstracto", "arte concreto" “constructivismo" podrán ser utilizados a lo largo del texto como sinónimos; sin embargo, se distinguirán específicamente estos términos cuando su sentido proponga inscripciones específicas centrales para el análisis.

4 BAYLEY, Edgar; CARADUJE Antonio; CONTRERAS, Simón; ESPINOSA, Manuel; GIROLA, Claudio; HLITO, Alfredo; IOMMI, Enio; LOZZA, Rafael; LOZZA, Raúl; LOZZA, R. V. D.; MALDONADO, Tomás; MOLENBERG, Alberto; MÓNACO, Primaldo; NÚÑEZ, Oscar; PRATI, Lidy y SOUSA, Jorge. Manifiesto Invencionista. Joaquim, $\mathrm{n}^{\circ}{ }^{9}$, Curitiba, marzo de I947, p. I2. En las próximas referencias se cita como VV.AA.. Manifiesto Invencionista. DRUMMOND DE ANDRADE, Carlos. Invencionismo. Joaquim, nº 9 , Curitiba, marzo de I947, p. I3.

5 ANTELO, Raúl. Coleccionismo y modernidad: Marques Rebêlo, marchand d’art. IN: Epílogos y prólogos para un fin de siglo. VIII Jornadas de Teoría e Historia de las Artes. Buenos Aires: CAIA, I999, p. I36-I37; ANTELO, Raúl. Confluencia. Literatura argentina por brasileños. Literatura brasileña por argentinos. Buenos Aires: Centro de Estudos Brasileiros, I982; ARTUNDO, Patricia M. Mário de Andrade e a Argentina: um pais e sua produção cultural como espaço de reflexão. São Paulo: EDUSP-FAPESP, 2004; ARTUNDO, Patricia M. (org.). Correspondência Mário De Andrade e Escritores / Artistas Argentinos. São Paulo: EDUSP-IEB, 20I3; SORÁ, Gustavo. Traducir el Brasil. Una antropología de la circulación de ideas. Buenos Aires: Del Zorzal, 2003. 


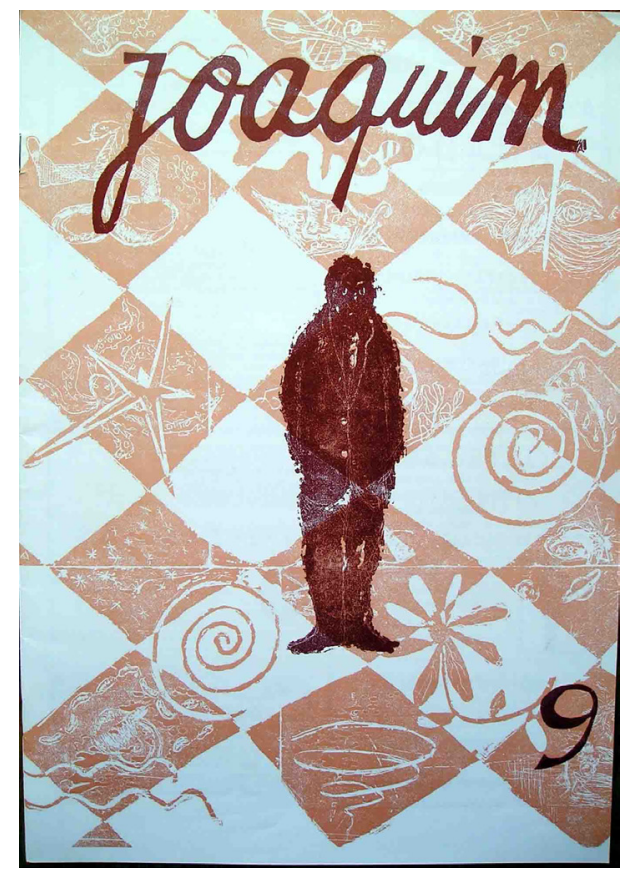

Ilustración I. A la izquierda: Joaquim, $\mathrm{n}^{\circ}$ 9, Curitiba. Tapa.

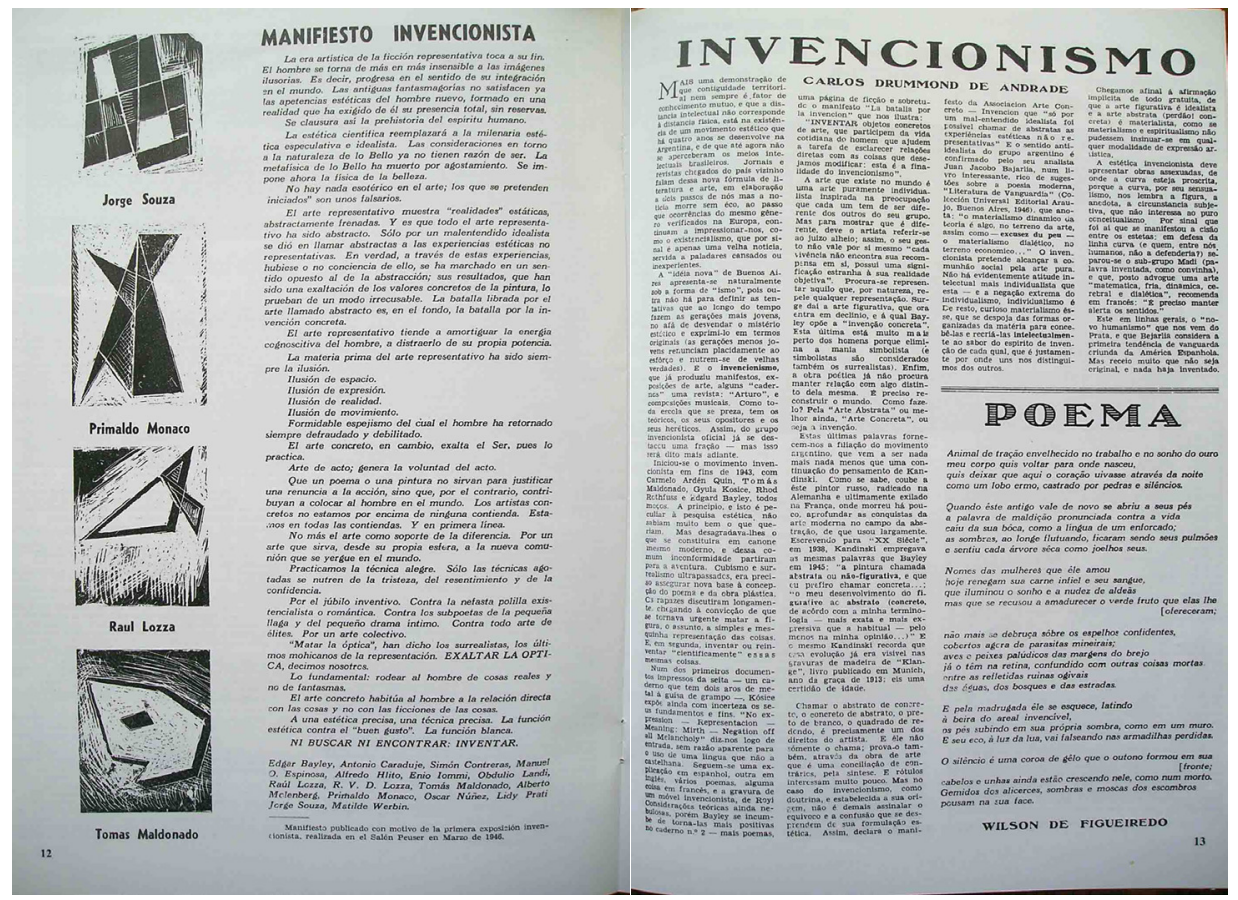

Ilustración 2 y 3. VV.AA., "Manifiesto Invencionista”, Joaquim, n 9, Curitiba, marzo de I947, p.I2.-I3 
El objetivo de este trabajo apunta a rastrear el postulado internacionalista que involucró a los proyectos abstraccionistas argentinos y la recepción que dichas propuestas tuvieron en el ámbito brasileño. En esta línea, se busca comprender la articulación de estos nuevos proyectos en función de la convergencia de una trama regional preexistente y analizar quiebres y disputas con otros núcleos culturales. Por lo tanto, este texto sostiene que la apuesta internacionalista de artistas y poetas argentinos y brasileños - montada en una estructura de vínculos previos se constituye en posicionamientos artísticos y compromisos políticos asumidos en el marco de la coyuntura regional de posguerra.

\section{LA AACI Y LA VANGUARDIA INVENCIONISTA PORTEÑA}

La vanguardia invencionista argentina se constituyó en torno a la revista Arturo. Revista de Artes Abstractas que despuntó con gestos vanguardistas en el campo artístico porteño en el verano de I944. Artistas y poetas unidos buscaban dar un anclaje propio a los significados del arte moderno y constituir una plataforma de acción estética transformadora que involucrase un proyecto internacionalista. El comité editorial del único número de Arturo estuvo integrado por Carmelo Arden Quin, Rhod Rothfuss, Gyula Kosice y Edgar Bayley. Además de sus noveles impulsores, la publicación reunió a "vanguardistas consagrados" activos en la renovación estética desde las primeras décadas del XX: además de Torres-García, participaron Vicente Huidobro, Murilo Mendes y Maria Helena Vieira da Silva. También se reprodujeron obras de Vassily Kandinsky y Piet Mondrian. La cubierta roja fue realizada por Tomás Maldonado y las viñetas del interior por Lidy Prati.

La revista representa un momento embrionario y aglutinador de ideas en ebullición. El invencionismo se proponía como un nuevo modo conceptual de abordar el hecho estético. Se privilegiaba la autonomía y los valores inventivos prescindiendo de cualidades descriptivas. También en esta línea se destacaban las capacidades intelectivas en la invención artística. Arturo aportó un procedimiento conceptual decisivo para la vanguardia invencionista porteña: el marco recortado. A través de esta indagación, estructuras irregulares que combinan formas geométricas simples se convirtieron en el soporte pictórico utilizado por los invencionistas.

Rasgos de profetismo y anticipación, supremacía de la novedad y actuación protagónica de un proceso revolucionario son marcas recurrentes en los manifiestos, boletines y revistas que sirvieron de soporte para la circulación de las ideas. Debates, conflictos y rupturas fueron también situaciones constantes en la articulación y desintegración grupal. Proliferaron nombres, asociaciones, manifiestos y panfletos, boletines y revistas. Existió una urgencia por definir cuál era esa nueva realidad inventiva y por constituir un aparato que sostuviera y extendiera la propuesta. La importancia otorgada a la constitución teórico-discursiva de los proyectos hace pensar, por momentos, que este aparato tuvo mayor centralidad que la obra plástica o, quizás, que la producción artística existía en función de la demostración de estos postulados. En este sentido, para estos grupos, el texto manifiesto se instaló como condición de su ruptura estética. 
En líneas generales, esta saga de la vanguardia local durante los años I940 puede sintetizarse en la ruptura con la representación figurativa y en su propuesta de invención de un nuevo tipo de objeto plástico. La ruptura con el cuadro de caballete y, por ende, la adopción del marco recortado, comportaba además de un cambio en la poética, una transformación en la función atribuida al arte. Evidentemente la necesidad de generar una propuesta que integrara las relaciones entre el arte y la vida era parte constitutiva de este cambio formal. Aunque las indagaciones de estos artistas se concentraron en investigar las posibilidades del marco recortado, las sutilezas entre los grupos resultan clave ya que dan cuenta de un modo diferenciado de pensar y actuar esta nueva realidad. Algunos artistas enfatizaron el modelo constructivo, el proceso analítico de creación y la búsqueda de intervención directa en la realidad en tanto objetivo de ese proyecto utópico. Esta voluntad transformadora entendida desde la teoría marxista se alineó a posiciones políticas que sostuvieron una evolución colectivista de la sociedad. Este es el caso la Asociación Arte Concreto-Invención (AACI) liderada por los hermanos Bayley y Maldonado. El grupo Madí, bajo la acción de Arden Quin, Kosice y Rothfuss, repensó la recuperación constructivista desde búsquedas lúdicas e incorporó la operación sobre el "sin-sentido" y aspectos destructivos. En este sentido, Dadá fue un referente importante para el gupo Madí. ${ }^{6}$ Para enmarcar los vínculos con Joaquim interesa reconstruir los lineamientos principales de la AACI, que realizó su primera exposición en el Salón Peuser en marzo de I946. Participaron allí Edgar Bayley, Lidy Prati y Tomás Maldonado presentes en Arturo, junto a otros integrantes quienes adscribieron al Manifiesto publicado en la hoja-catálogo.? El manifiesto está básicamente marcado por la incorporación de la teoría y el vocabulario marxista a una lectura evolutiva del arte moderno. Filtraciones teórico-discursivas con el pensamiento marxista se suman a un recorrido modernista de liberación mimética de la imagen y énfasis creativo a partir de las materialidades artísticas. Asimismo, la línea del Productivismo ruso sostenida por el grupo Lef (integrado por Vladimir Mayakovsky, Boris Arvatov, Osip Brik, Aleksandr Rodchenko, Varvara Stepanova y Vladimir Tatlin, entre otros) parece ser la fuente donde se imbricó la búsqueda de los artistas concretos argentinos. Maldonado ha mencionado esta línea productivista y más precisamente los textos de Arvatov y Brik como el marco para la reelaboración de las problemáticas artísticas y la apuesta revolucionaria. ${ }^{8}$

6 Sobre el desarrollo de los grupos invencionistas, véase: GARCÍA, María Amalia. El arte abstracto. Intercambios culturales entre Argentina y Brasil. Buenos Aires: Siglo XXI, 20II; ROSSI, Cristina. Las utopías constructivas en la posguerra rioplatense. Tesis de doctorado, Facultad de Filosofía y Letras, UBA, 20Io, mimeo; PÉREZ-BARREIRO, Gabriel (cur.). The Geometry of Hope. Latin American Abstract Art from the Patricia Phelps de Cisneros Collection. Austin: The Blanton Museum-University of Texas at Austin, 2007; DE MAISTRE, Agnès. Les groupes Arte Concreto-Invención et Madí. IN: Art d’Amérique Latine I9II-I968. Paris: Musée National d’Art Moderne. Centre Georges Pompidou, I992, p. 336-348; PERAZZO, Nelly. El Arte Concreto en la Argentina. Buenos Aires: Gaglianone, I983.

7 VV.AA. Manifiesto Invencionista. $I^{a}$ Exposición de la Asociación Arte concreto-invención, Buenos Aires, Salón Peuser, I8 de marzo al 3 de abril de I946. Véase nota 2.

8 MALDONADO, Tomás. Vanguardia y racionalidad. Barcelona: Gustavo Gili, I977, p. 37. 
La AACI publicó en el mes de agosto de I946 el primer número de la revista Arte Concreto-Invención. La revista tiene un formato mediano y dieciséis páginas; la tapa está estructurada en base a rectángulos y las letras que están organizadas a partir de un juego negativo-positivo sobre blanco y negro. Allí se publicó nuevamente el "Manifiesto Invencionista" en la página ocho acompañada de fotografías de los marcos recortados de los miembros del grupo. Precisamente esta página es la que fue reelaborada y publicada en Joaquim.
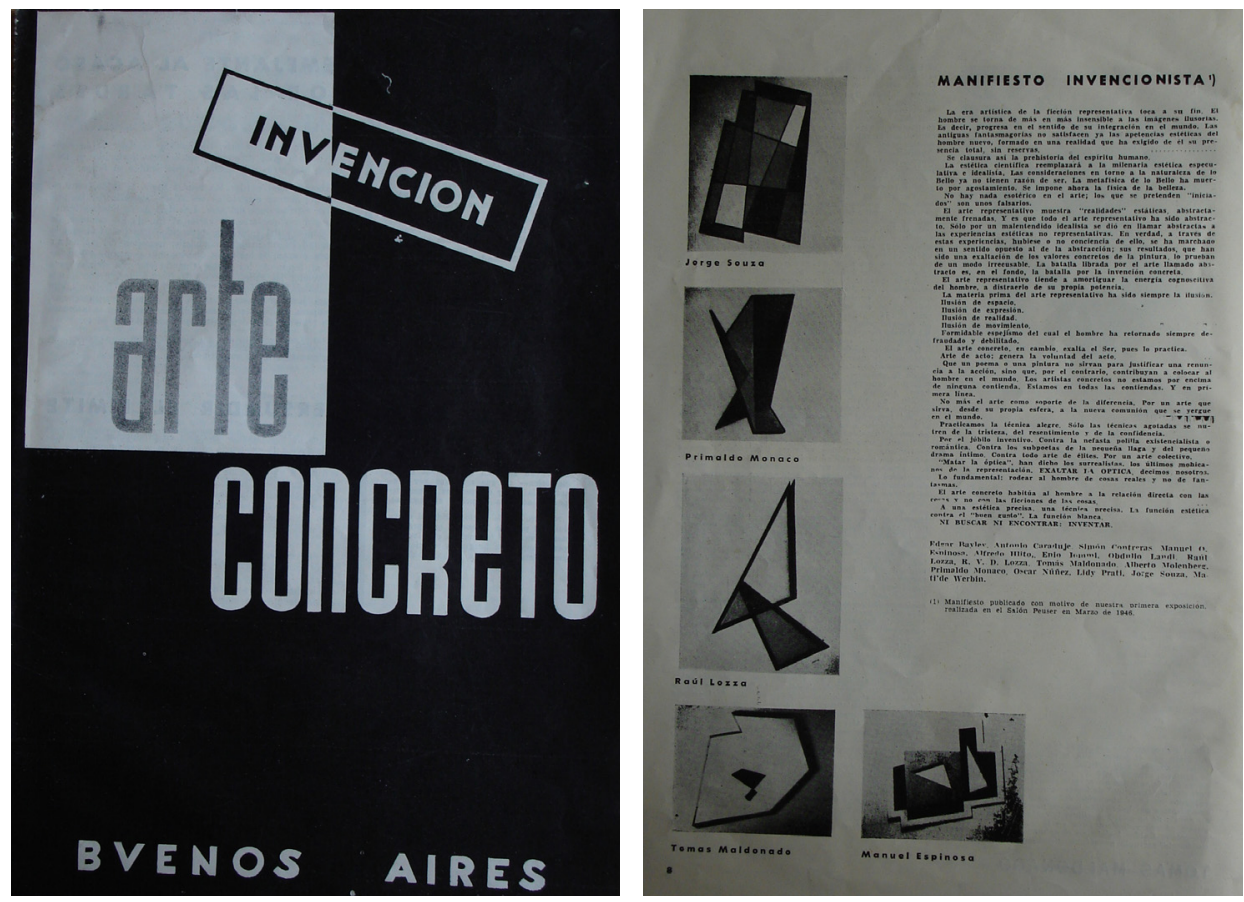

Ilustración 4 y 5. A la izquierda: Arte Concreto-Invención, $\mathrm{n}^{\circ} \mathrm{I}$, Buenos Aires, agosto de I946, tapa. A la derecha: VV.AA...,"Manifiesto Invencionista", Arte Concreto-Invención, $\mathrm{n}^{\circ} \mathrm{I}$, Buenos Aires, agosto de I946, p. 8.

En I946 la AACI realizó, luego, de la primera muestra en Peusewr por lo menos tres exposiciones más y se incorporaron nuevos integrantes. Evidentemente, se trataba de un momento de apertura, de dar a conocer experiencias que proponían un violento replanteo de las producciones locales. La estrategia parece haber sido afianzarse en el campo artístico aunque sosteniendo una actitud virulenta de modo de obtener repercusiones. En relación con las exposiciones, aparecieron en la prensa artículos sobre las intervenciones del grupo. Algunos más amables y otros no tanto, en su mayoría, señalaban antecedentes fuertes que opacaban la fractura que los invencionistas buscaban sustentar. ${ }^{9}$ Vizconde de Lascano Tegui desde El

9 Exposición de Arte Concreto. La Prensa, Buenos Aires, 23 de marzo de I946, p. 9; Arte Concreto. La Nación, Buenos Aires, 20 de marzo de I946, p.4 y los siguientes artículos. 
Mundo miraba con desconfianza y calificó la exposición de Peuser como "un grupo de pintores en capilla, tocándose codo a codo - muchos con el espíritu de uno

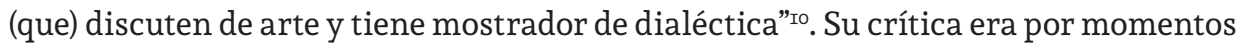
muy provocativa: refiriéndose a ellos como los “jóvenes estetas”; los acusaba de mala factura y poca investigación cromática.

Mucho más acogedor resultó el artículo de Romualdo Brughetti en el número cuatro de Cabalgata. Sin ser demasiado específico ni crítico, Brughetti se limitó a contar una historia fáctica de los grupos y a intentar señalar las diferencias. Respecto de las intervenciones de los grupos de jóvenes, Brughetti no se arriesgaba a más y confesaba sus preguntas: “Es una actitud polémica cuyas desviaciones pueden traer fecundas experiencias creativas?”I

La ironía cargó la pluma del articulista de Qué sucedió en 7 días cuando en tres oportunidades se refirió a estas nuevas propuestas: son notas sin firmar pero, dado que Julio E. Payró escribía en la revista y participaba del grupo editorial es factible su atribución. Refiriéndose a la I ${ }^{a}$ Exposición Madí en la Galería Van Riel en los primeros días del mes de agosto, consideraba que los aportes del grupo eran novedosos en Buenos Aires, pero no en términos mundiales: entendía a estas búsquedas locales como un eslabón perdido en la serie de ecos que los movimientos de avanzada habían tenido en la Argentina. ${ }^{\mathrm{I2}}$

En líneas generales, estas propuestas resultaron interesantes para la crítica de arte; sin embargo, es evidente que no se toleraba la petulancia de novedad con la cual los grupos buscaban sostenerlas. De todas formas, la AACI tuvo su propio crítico que colaboró en sostener y difundir la propuesta. Juan Jacobo Bajarlía abogado y poeta y muy amigo de Edgar Bayley editó en 1946 el libro Literatura de vanguardia del "Ulises" de Joyce y las escuelas poéticas donde dedicó el capítulo "La batalla por el invencionismo estético" al arte concreto en la Argentina.

Dada su vinculación con el grupo, fue quien logró interpretar y explicar de un modo más completo estas ideas. En primer lugar, es interesante el giro retórico que utilizó para dar cuenta de las vinculaciones entre marxismo y arte moderno: "el materialismo dinámico sería, en el nuevo arte social, lo que es el materialismo dialéctico en la doctrina científica de la economía"זз. En segundo lugar, es atractivo cómo Bajarlía reparó en el quiebre del marco y su integración a la imagen en tanto creación del objeto como nueva categoría estética. Asimismo, sus análisis fueron elocuentes y provocaron reacciones; refiriéndose a los marcos recortados Bajarlía sostenía que los artistas de la AACI "desecharon el plano unitario y arremetieron contra la curva. Su estética debía presentar obras asexuadas y no era conveniente

Io V. de L. T. [LASCANO TEGUI, Vizconde de]. Modernos y pasatistas. El Mundo, Buenos Aires, 6 de abril de I946, p. I4.

II BRUGHETTI, Romualdo. Un mundo más puro y sencillo. El arte abstracto en la Argentina. Cabalgata, $\mathrm{n}^{\circ}$ 4, Buenos Aires, I9 de noviembre de I946, p. 6.

I2 S/a [PAYRÓ, Julio E.] La caída del marco. Qué sucedió en 7 días, Buenos Aires, I5 de agosto de I946, p. 34-35. I3 BAJARLÍA, Juan Jacobo. Literatura de vanguardia. Del "Ulises" de Joyce a las escuelas poéticas. Buenos Aires: Araujo, I946. p. I60. 
que una arista cóncava o convexa le diera a la imagen, una pátina figurativa de un estado físico personal"I4.

Estas revistas y manifiestos, junto con el libro de Bajarlía, atravesaron el Río de la Plata encontrando interés en Brasil: Carlos Drummond de Andrade publicó el Ier de diciembre de I946 en el diario carioca Correio da manhã un artículo reseñando las intenciones del concretismo argentino. ${ }^{15}$ Este artículo daba cuenta de su conocimiento sobre estos nuevos emprendimientos argentinos y mientras, en principio, valoraba "su novedad" ensayaba reflexiones críticas sobre sus postulados. El comienzo de su artículo era rotundo:

Mais uma demonstração de que a contigüidade territorial nem sempre é fator de conhecimento mutuo, e que a distância intelectual não corresponde à distância física, está na existência de um movimento estético que há quatro anos se desenvolve na Argentina, e de que até agora não se aperceberam os meios intelectuais brasileiros. [...] A "idéia nova" de Buenos Aires apresenta-se naturalmente sob a forma de "ismo" [...] É o invencionismo, que já produziu manifestos, exposições de arte, alguns "cadernos", uma revista, Arturo, e composições musicais. ${ }^{16}$

En este texto Drummond planteaba las desmembraciones ocurridas en la "secta" original y comprendiendo las circunstancias de los jóvenes argentinos las justificaba explicando que "a princípio, e isto é peculiar à pesquisa estética, não sabiam muito bem o que queriam”ㄱ. Exponía los principales puntos del programa invencionista y pasando revista a los materiales que tenía encontraba inciertos algunos de los fundamentos propuestos. Se refirió a las incertezas del cuaderno Invención I de Gyula Kosice encontrando sin razón (¿o snob?) la inclusión de textos en inglés y francés. Más explicativo le pareció el cuaderno número dos de Bayley: a partir del análisis de "La batalla por la invención" sintetizaba el planteo y, remitiendo a Kandinsky, extraía conclusiones sobre los orígenes de estas ideas. Luego analizaba el "Manifiesto invencionista" para marcar el equívoco y la confusión que él encontraba en esta fórmula estética: "O invencionismo pretende alcançar a comunhão social pela arte pura. Não há evidentemente atitude intelectual mais individualista que esta - e a negação extrema do individualismo, individualismo é"I8.

Evidentemente Drummond no estaba dispuesto a aceptar algunos perfiles de maniqueísmo conceptual que sostenía la nueva idea del Plata; convocaba a la ironía y al sentido común con el objeto de desenmascarar la cuestión: "Chegamos afinal à afirmação implícita de todo gratuita, de que a arte figurativa é idealista e a arte

\footnotetext{
I4 Idem, p. I75.

I5 DRUMMOND DE ANDRADE, Carlos. Invencionismo. Correio da Manhã, Rio de Janeiro, I de diciembre de I946, seção 2, p. I. Reeditado y traducido en Raúl Antelo (org.), Confluencia..., Op. cit., p. I67-I7I.

I6 DRUMMOND DE ANDRADE, Carlos, "Invencionismo”, Op. cit.

I7 Idem, ibidem.

I8 Idem,ibidem.
} 
abstrata (perdão! concreta) é materialista, como se materialismo e espiritualismo não pudessem insinuar-se em qualquer modalidade de expressão artística"ı

El análisis de Bajarlía en Literatura de vanguardia... sobre lo cóncavo y convexo en función de la sexualidad de las obras era un punto donde Drummond se detenía risueñamente para disentir profundamente con el planteo y afirmarse en la "humanidad" de la curva: "e quem, entre nós humanos, não a defenderia?" En contraposición con el augurador comienzo, Drummond terminaba su artículo bastante escéptico respecto de la originalidad e "invención" de la propuesta argentina.

Probablemente este haya sido el comienzo del fuerte lazo que se establecería entre Bayley y Drummond, siendo el primero difusor de la poesía del brasileño en la Argentina y un gran admirador. Para comprender estos recorridos es preciso reconstruir una trama de relaciones subyacente que vehiculizó y fue permeable a la transmisión de esta "nova ideia de Buenos Aires".

\section{LA ACTUALIZACIÓN DE LA TRAMA REgIONAL}

La exposición 20 artistas brasileños organizada por Marques Rebêlo y traída a la Argentina en I945 en colaboración con Emilio Pettoruti, director del Museo Provincial de Bellas Artes de La Plata, permite enmarcar los nuevos nexos activos en esta estructura de vínculos preexistente entre argentinos y brasileños. ${ }^{20}$ Esta exposición se sumó a las iniciativas de integración regional que remitían a los viajes de Emilio Pettoruti a Rio de Janeiro a finales de los años 20, el exilio de Newton Freitas y Lidia Bessouchet a la Argentina en I937 y la difusión de Mário de Andrade durante los añosi940 en las revistas antifascistas como Argentina Libre y Correo Literario, entre otros puntos de contacto intelectual entre ambos países. ${ }^{2 \mathrm{I}}$

Entre el 2 y el I9 de agosto de I945, 20 artistas brasileños tuvo lugar en el Museo Provincial de Bellas Artes de La Plata y fue reabierta en Buenos Aires en los Salones Nacionales de Exposición del 25 de agosto al 7 de septiembre. También fue exhibida en Montevideo. Tanto la exposición como la estadía de Marques Rebêlo en Buenos Aires por más de seis meses generaron un fuerte proceso de intercambio. Marques Rebêlo recorrió museos y centros culturales en el interior de la Argentina dando conferencias con proyecciones de imágenes y recitación de poesías para exponer diversos aspectos de la cultura brasileña. ${ }^{22}$ La actividad de Rebêlo tuvo buena

I9 DRUMMOND DE ANDRADE, Carlos, "Invencionismo", Op. cit.

20 ANTELO, Raúl. Coleccionismo y modernidad... Op. cit.

2I ARTUNDO, Patricia M. Mário de Andrade e a Argentina..., Op. cit.; ANTELO, Raúl. Confluencia. Literatura argentina por brasileños... Op. cit.

22 Marques Rebêlo, carta a Carlos Drummond de Andrade, Buenos Aires, 9 de julio de I945, CDA-CP- I45I, Biblioteca-Arquivo de Literatura Brasileira “Casa Rui Barbosa”, Rio de Janeiro. 
recepción y muy entusiasmado con la experiencia, le contaba por carta a Drummond de Andrade sobre la tarea de difusión de la cultura brasileña que estaba realizando. ${ }^{23}$

En relación con la proyección de la muestra, el Museo Nacional de Bellas Artes adquirió seis obras de 20 artistas brasileños, entre ellas Cidadezinha de Tarsila do Amaral y Mulher chorando de Cândido Portinari; ${ }^{24}$ además el Museo Provincial de La Plata y el Museo Municipal de Bellas Artes de Montevideo también adquirieron obras para sus colecciones. Asimismo este interés por la cultura brasileña se manifestó en la aparición a fines de 1945 en el libro La pintura brasileña contemporánea de Jorge Romero Brest, publicado por Poseidón, que ofició casi como catálogo de la muestra. También la editorial Nova, dirigida por Luís Seoane, publicó Pequeña antología de cuentos brasileños organizada por Marques Rebêlo y traducida al español por Raúl Navarro.

Es preciso detenerse en el libro La pintura brasileña contemporánea que fue producto directo de la exposición. En este libro con cubierta que reproducía el premiado Café de Cándido Portinari Romero Brest lanzaba sus impresiones sobre un panorama artístico que, salvo algunas reproducciones aisladas, sólo había tenido oportunidad de contrastar en la exposición de Rebêlo y Pettoruti. Sabía que sus materiales eran sumamente fragmentarios y, dado que no había tenido todavía oportunidad de viajar a Brasil, dejaba asentadas sus excusas y su objetivo: "Hagamos un esfuerzo, pues, los hombres del sur de este continente, los que tenemos raíces hispánicas y una arborescencia italiana, francesa, inglesa o alemana, para comprender con emoción esa realidad indígena, lusitana y negra que comienza a expresarse con facundia feroz en todos los planos de la cultura brasileña"25.

La crítica paulista y carioca recibió calurosamente el libro. Un intercambio de legitimidades se dio entre el crítico y los círculos artísticos brasileños. Numerosos artículos elogiaban la publicación, el esfuerzo del crítico y la importancia de este reconocimiento extranjero a la pintura brasileña. Sin embargo, algunos críticos anotaban las inexactitudes en las que incurría Romero Brest a causa de una falta de conocimiento profundo. ${ }^{26}$ Varios artículos coincidían en que no había podido elaborar juicios propios: Rubens Navarra anotaba que "quando a coisa aperta muito,

23 Idem, ibidem. Marques Rebêlo, carta a Carlos Drummond de Andrade, Rosario, I4 de septiembre de I945; Marques Rebêlo, carta a Calos Drummond de Andreade, Buenos Aires, 3 de mayo de I945, CDA-CP- I45I, Biblioteca-Arquivo de Literatura Brasileira "Casa Rui Barbosa”, Rio de Janeiro. Carpeta de recortes "Rebêlo, Marques”, Biblioteca-Arquivo de Literatura Brasileira “Casa Rui Barbosa”, Rio de Janeiro.

24 Según consta en el inventario del Museo Nacional de Bellas Artes, Buenos Aires: Tarsila do Amaral, Pueblito, I945, $\mathrm{n}^{\circ}$ de inventario 6680; Cândido Portinari, Mujer llorando, I944, $\mathrm{n}^{\circ}$ de inventario 6678; Roberto Burle Marx, Mujeres, I945, $\mathrm{n}^{\circ}$ de inventario 6679; José Pancetti, Paisaje, I945, $\mathrm{n}^{\circ}$ de inventario 6682; Tomas Santa Rosa Junior, III H. C., s/d, nº de inventario 668; Clovis Graciano, Punta seca, I945, $\mathrm{n}^{\circ}$ de inventario 6683. 25 ROMERO BREST, Jorge. La pintura brasileña contemporánea. Buenos Aires: Poseidón, I945, p. 9.

26 Luis Martins subrayaba el desconocimiento de Almeida Junior entre los precursores del naturalismo y además, al igual que Sérgio Milliet, le marcaba la escasa relevancia que le daba a los artistas paulistas como Volpi o Bonadei. Véase MARTINS, Luis La pintura brasileña contemporánea. O Estado de São Paulo, 4 de marzo de I946, caja I sobre 5, documento I07, Archivo Jorge Romero Brest, FFyL-UBA; Sergio Milliet, carta a Jorge Romero Brest, São Paulo, 6 de mayo de I946, documento 362, Archivo Jorge Romero Brest, FFyL-UBA. 
ele se socorre da opinião dos críticos brasileiros como ponto de apoio"27. El mismo Navarra, Frederico Baratta, Freitas, Manuel Bandeira, Sérgio Milliet y Gilberto Freyre eran citados en el ensayo de Romero Brest, pero el eje de su texto estaba marcado por las ideas de Mário de Andrade. De hecho, respecto del llamado a los "hombres del sur" con el que Romero Brest introducía las expectativas del libro, Navarra anotaba que el crítico argentino "toma pois, do lado de fora, a mesma posição que Mário de Andrade tomara de dentro" 28 . Era la línea de este escritor paulista y sus preocupaciones en torno a las definiciones de lo nacional lo que guiaba el planteo del crítico argentino. Indudablemente bajo esta concepción Portinari era el artista referente.

Resulta evidente que fue la misma trama de intelectuales y artistas ya establecida (Mário de Andrade, Romero Brest, Marques Rebêlo, Pettoruti etc.) la que vehiculizó estas nuevas conexiones. Si Drummond de Andrade comentó en diciembre de 1946 en el diario carioca Correio da Manhã las propuestas del invencionismo argentino contando con todas las publicaciones que había producido el grupo resulta claro que las interacciones de esta red funcionaron de puente para la propuesta. Además de la permanencia de Marques Rebêlo en Buenos Aires por más de seis meses en ocasión de la exposición, Raúl Navarro, traductor y amante de la literatura brasileña, estuvo en Brasil en 1946 invitado por el Servicio de Cooperación intelectual de Itamaraty. ${ }^{29}$

Un núcleo clave en esta trama de relaciones con Brasil fue la revista Contrapunto (I944-I945). Contrapunto fue un espacio receptivo a este "momento brasileño" en la Argentina que desató Marques Rebêlo y su exposición. En el número cinco, además del anuncio de 20 artistas brasileños, aparecieron publicados los poemas "Mundo Mayor" de Carlos Drummond de Andrade y "Lámpara Marina" de Jorge de Lima, traducidos al español por Raúl Navarro. ${ }^{30}$ Acompañaba la puesta en página la reproducción de Antropofagia de Tarsila do Amaral. En el número seis, Leonardo Estarico resaltaba a las principales figuras de la plástica brasileña mientras realizaba una semblanza entre el proceso colonizador en dicho país y su desarrollo cultural..$^{\text {in }}$ En este sentido, Raúl Lozza ha afirmado que los contactos brasileños de la AACI se dieron a través de Marques Rebêlo y su propia actividad en la mencionada publicación..$^{32}$

Reflexionando sobre esta "arqueología" de relaciones, Raúl Antelo resalta que la lógica de 20 artistas brasileños "es, de cierto modo, inseparable de una historia de la

27 NAVARRA, Rubens. Um livro sobre a pintura brasileira. Diário de Noticias, s/d, I946, caja I sobre 5, documento Io6A, Archivo Jorge Romero Brest, FFyL-UBA

28 Idem, ibidem.

29 "Há atualmente na Argentina enorme interesse pela literatura brasileira", Folha de Minas, Belo Horizonte, I2 de septiembre de I946; “Grande interesse pela literatura brasileira, na Argentina”, O Diário, Belo Horizonte, I2 de septiembre de I946. Carpeta de recortes, Biblioteca-Arquivo de Literatura Brasileira "Casa Rui Barbosa”, Rio de Janeiro.

30 DRUMMOND DE ANDRADE, Carlos. Mundo Mayor. Contrapunto, $\mathrm{n}^{\circ}$ 5, Buenos Aires, agosto de I945, p. 7; LIMA, Jorge de. Lámpara Marina. Contrapunto, $\mathrm{n}^{\circ}$ 5, Buenos Aires, agosto de I945, p. 7.

3I ESTARICO, Leonardo. Veinte pintores brasileños. Contrapunto, n 6, Buenos Aires, octubre de I945, p. II. 32 LOZZA, Raúl, entrevistas con la autora, I de julio de 2004 y 5 de agosto de 2004. 
abstracción y una historia de la humanización entendida como fraternización”33. Su planteo es clave para este argumento ya que la publicación del artículo de Drummond en el diario Correio da Manhã y en Joaquim y las intervenciones de la AACI en esta revista convergieron en una trama de relaciones preexistente que se rearticuló en función de una mudanza de los intereses de intercambio.

Drummond era un referente estético y político en el cual los invencionistas encontraban un aliado para sus propios proyectos. Ni bien Bajarlía logró conseguir la nota aparecida en Correio da Manhã a través de la embajada brasileña se dispuso a escribirle.34 Le agradecía muy gentilmente que se hubiera ocupado de Literatura de vanguardia encomiando su labor, aunque dejaba traslucir que algunos puntos de su artículo "Invencionismo" debían aclararse: ningún artista concreto aceptaba la crítica de falta de solidez en sus teorías. Pero Drummond tenía un faro intelectual y a Bajarlía le interesaba mantener fluidez en el contacto. En la segunda carta que le escribe, decía:

He recibido su, hasta ahora, opera omnia poética. Ya tiene usted un puesto en las letras de América. Y entendiéndolo así, ya me había tomado la libertad de hablar de sus poemas a mis amigos y a los jóvenes escritores de la Argentina, entre los cuales me cuento. Por otra parte, mucho antes de recibir la Poesía até agora, me había dado a la tarea de traducir la "Economia dos mares terrestres" de Rosa do povo, la cual aparecerá en el Caballo de Fuego, revista antológica de poesía dirigida por Antonio de Undurraga. ${ }^{35}$

Precisamente, en el número tres de Caballo de Fuego apareció la traducción de Bajarlía y “Telegrama” de Murilo Mendes traducidos por Carmelo Arden Quin. ${ }^{36} \mathrm{En}$ agosto de I948, en el primer número de Contemporánea la revista de Bajarlía se hacía referencia a la aparición de Poesía até agora y se publicaba la traducción de algunos de sus versos. ${ }^{37}$ Bajarlía le enviaba las revistas y le contaba a Drummond sobre sus proyectos: [Contemporánea], "como podrá observar, la dirijo yo con el esfuerzo de la gente joven y más inteligente de Bs. As. Está impregnada de un aliento original y pretende ser una avanzada revolucionaria en las letras y las artes." ${ }^{38}$ Bajarlía continuó escribiéndole a Drummond sus opiniones sobre el ambiente porteño y exponiendo su compromiso con el concretismo a través de los emprendimientos que llevaba a cabo en Buenos Aires.

33 ANTELO, Raúl. Coleccionismo y modernidad: Marques Rebêlo, marchand d’art. Op. cit., p. I37.

34 Juan Jacobo Bajarlía, carta a Carlos Drummond de Andrade, Buenos Aires, 5 de marzo de I947. CDA-CP- I66. Biblioteca-Arquivo de Literatura Brasileira “Casa Rui Barbosa”, Rio de Janeiro.

35 Juan Jacobo Bajarlía, carta a Carlos Drummond de Andrade, Buenos Aires, I6 de marzo de I948. CDA-CPI66. Biblioteca-Arquivo de Literatura Brasileira “Casa Rui Barbosa”, Rio de Janeiro.

36 Caballo de Fuego, año III, n 3, Buenos Aires, I948, p. 6. Véase también DRUMMOND DE ANDRADE, Carlos. El enigma. Caballo de Fuego, año IV, nº, Buenos Aires, I950, p. 5, traducción Juan Jacobo Bajarlía.

37 Tronera. Contemporánea. La revolución en el arte, $\mathrm{n}^{\circ} \mathrm{I}$, Buenos Aires, agosto de I948, p. 3.

38 Juan Jacobo Bajarlía, carta a Carlos Drummond de Andrade, Buenos Aires, 4 de agosto de I948. CDA-CPI66. Biblioteca-Arquivo de Literatura Brasileira “Casa Rui Barbosa”, Rio de Janeiro. 
[...] nosotros debemos defendernos contra las fuerzas regresivas que se escudan en los defecatorios de los diarios. integrados en una suerte de lucha descabezada, no daremos cuartel a los que pretenden olvidar que el arte es lucha y que esta lucha se objetiva en los valores revolucionarios que condicionan sus vivencias. seremos una hidra más, pero no al modo de la mitológica que pierde al fin todas sus cabezas, sino la hidra que crece monstruosamente para desintegrar toda huella de regresión al pasado.39

En esta trama de revistas de gente joven que buscaba la transformación estaba Joaquim. Esta publicación de Curitiba dirigida por Dalton Trevisan fue sumamente sensible a las colaboraciones porteñas: como ya se ha señalado "Invencionismo" fue republicado en el número nueve y en la página contigua Joaquim publicó el "Manifiesto Invencionista" de la AACI (en español) acompañado de las reproducciones de los marcos recortados de Tomás Maldonado, Jorge Souza, Primaldo Mónaco y Raúl Lozza en sus versiones gráficas. El grabado, asociado a la ilustración literaria y a las imágenes de contenido social, era esta vez utilizado para dar visualidad a la modernidad abstracta.

Es interesante observar que la revista de Curitiba reeditó la página ocho de Arte Concreto-Invención donde aparecía el manifiesto también acompañado por los marcos recortados de los mismos artistas. Sin embargo, la reproducción fotográfica de las obras utilizada en la revista porteña había sido reemplazada en Joaquim por una resolución gráfica. El pasaje de técnica, que se justificaba en la reposición de estas imágenes en este nuevo contexto, plantea algunas cuestiones interesantes. Es preciso vincular esta intervención a la efervescencia gráfica de los Clubes de Gravura desarrollados fundamentalmente en Porto Alegre, pero también en Curitiba, en São Paulo y en Recife. $4^{\circ}$ La marca visual de la revista estaba en la utilización de imágenes directamente grabadas sobre los clichés de impresión. Esto le otorgó a la publicación un carácter artístico inusitado a la par que obligaba al grabador a la improvisación en la realización. Quirino Campofiorito explicaba que esta decisión editorial era un elemento que realzaba y distinguía a la publicación de otras revistas literarias: "Obrigado o artista a fugir do original executado sobre o papel e que é transportado para o metal por processo fotográfico afim de ser gravado no metal, obriga-se ele a um trabalho de surpreendente espontaneidade (....) Cada número parece assim como uma joia cuidadosamente burilada manualmente." ${ }^{4}$

Bajo esta norma de trabajo ilustrativo, la revista de Curitiba debió reinterpretar en su clave gráfica lo que había recibido de la revista porteña. Si bien se reproducen las mismas obras que en la publicación porteña (con la excepción del marco recortado de Manuel Espinosa) en la versión curitibana estos marcos recortados son reelaborados a partir del trabajo sobre la matriz de impresión. Aunque es posible reconocer las obras, esta reinterpretación se tradujo en licencias e inversiones respecto de las características y propuestas originales. De hecho, esta reinterpretación técnica

39 Juan Jacobo Bajarlía, carta a Carlos Drummond de Andrade, Buenos Aires, 24 de enero de I949. CDA-CP-I66. Biblioteca-Arquivo de Literatura Brasileira “Casa Rui Barbosa”, Rio de Janeiro. Minúsculas en el original.

40 AMARAL, Aracy. Arte para quê? A preocupação social na arte brasileira I930-I970. São Paulo: Nobel, 2003, p. I75-I87.

4I CAMPOFIORITO Quirino. Os ilustradores de Joaquim. Joaquim, nº, Curitiba, p. Io. 
generó una lectura ambigua y hasta contradictoria con lo que sostenían las obras invencionistas. Por un lado, los marcos recortados aparecen como combinaciones de figuras geométricas representadas sobre un fondo en el que se distinguen entre sí a través de la utilización de texturas visuales otorgadas por la técnica escogida. Por otra parte, si se consideran las evaluaciones que efectuaba el artista y crítico paulista Campofiorito sobre estas interpretaciones técnicas es evidente que nada tenían que ver con las bases del invencionismo: "Clichês diretamente trabalhados no material definitivo, com os traços indisfarçáveis das surpresas de execução que ficam como pegadas deixadas pela personalidade do artista na luta por expressar-se" ${ }^{\prime \prime 2}$.

Evidentemente, la interacción en otros circuitos generaba marcas en el propio proyecto. La traducción involucraba una reinterpretación que no siempre resultaba exacta. Sin embargo, más allá de la fidelidad en la lectura de la propuesta lo importante radicaba en la extensión, difusión y apropiación de estas ideas. El exceso de radicalismo, los dogmas y la autoexclusión vanguardista debía soslayarse si se quería abordar un mundo de relaciones. En este sentido, la trama ya estaba activada y la revista Joaquim se constituyó en espacio receptivo y en un soporte permeable a la transmisión. Sólo observando las tapas de Joaquim (todas con base figurativa) es posible deducir que los miembros de la AACI habían relajado su dogmatismo en función de privilegiar la interacción; a su vez, la revista de Curitiba estaba ávida por captar todo aquello que pudiese contribuir a abrir el encierro provinciano.

En un contexto de modernización general del Brasil, las nuevas generaciones buscaron subvertir el orden provinciano del Estado de Paraná. ${ }^{43}$ Los jóvenes de Curitiba, presionados por las tensiones del contexto internacional, buscaron integrarse a la vida contemporánea: "É a descoberta súbita (e, bastante atrasada, mas nem por isso menos entusiasta) da arte moderna que faz que os moços de Curitiba, liderados por Dalton Trevisan, criem Joaquim"44. Además de Trevisan, el comité editorial estaba integrado por Erasmo Pilotto y Antônio Walter; asimismo, los artistas Poty Lanzarotto y Guido Viaro fueron piezas clave para la creación de la publicación. ${ }^{45}$ La publicación manejó dos líneas en simultáneo: la lucha doméstica contra los arcaísmos paranistas y la búsqueda de apertura nacional e internacional.

Como toda revista que aspira a la renovación estética, el número uno tiene en la portada su correspondiente manifiesto: el "Manifesto para não ser lido". Éste es un collage de fragmentos de textos de diversos escritores: aparecen "suscribiendo" con sus ideas Rainer Maria Rilke, John Dewey, André Gide, Mayakovsky, Sérgio Milliet, Otto Maria Carpeaux y Paul Verlaine. La singularidad de este escrito radicaba en que

42 Idem, ibidem.

43 FREITAS, Artur. A consolidação do moderno na história da arte do Paraná: anos 50 e 60. Revista de História Regional, ${ }^{\circ}$ 8, Invierno 2003, p. 87-I24.

44 SANCHEZ NETO, Miguel. Joaquim: modernidade periférica e dupla ruptura. IN: SCHWARTZ, Jorge y PATIÑO, Roxana, Revista Iberoamericana: Revistas literarias/culturales latinoamericanas del siglo XX, $\mathrm{n}^{\circ}$ 208-209, Pittsburgh University, 2004, p. 864.

45 TREVISAN, Dalton. Emiliano, poeta mediocre. Joaquim, $\mathrm{n}^{\circ}$ 2, Curitiba, junio de I946, p. I6. SOARES DE OLIVERA, Luiz Cláudio. Joaquim contra o Paranismo. Tesis de Maestria, Universidade Federal do Paraná, Curitiba, 2005 . 
no estaba firmado por los editores y en que las ideas "de combate" se expresaban desde otras voces. La diversidad textual de este collage-manifiesto revela la naturaleza fragmentaria del ideario de la revista. ${ }^{6}{ }^{6}$ En este sentido, Joaquim se fijó en un espacio estratégico que le permitió mantener cierta distancia de las ortodoxias artísticas; bastaba ser contemporáneo para ser aceptado en el sumario de la publicación.

En el mismo número en el que fue publicado el "Manifiesto Invencionista", las versiones gráficas de los marcos recortados y el texto de Drummond, Dalton Trevisan ajustaba sus ideas en el artículo "A geração dos vinte anos na ilha". En este texto Trevisan marcó la línea de la publicación. Este establecimiento de principios no tuvo lugar, como es común, en el número inicial, pero sí en el ejemplar noveno acompañado de la radicalidad de la propuesta argentina. En este artículo, Trevisan utilizó metáforas que buscaban definir el aislamiento de estos jóvenes marcando la necesidad de integrarse y participar en el tiempo presente. "Porque nós, últimos moços da última província do Paraná, não declinamos de nossa responsabilidade na marcha dos acontecimentos". ${ }^{47}$ La guerra había generado un consenso internacionalista promoviendo la abolición de las fronteras; los problemas se extendían más allá de las circunscripciones nacionales y se transformaban en un conflicto para toda la humanidad.

O importante foi a decisão de romper com o passado, nas suas tradições estéreis. É pois uma geração sem medo. Nós, os filhos da Segunda Guerra não fomos poupados pelos acontecimentos e aprendemos na própria carne que somos parte íntima deles. O mundo é um só; os nossos problemas estéticos ou vitais, são os mesmos dos moços de Paris ou dos moços de Moscou. Com amor ao mundo no peito, seja o nosso canto impregnado de terra, homem, liberdade. $4^{8}$

Luchar contra este encierro implicaba borrar el adjetivo "paranista" que definía una identidad reductora y peligrosa: "Nossa geração, que reclama o seu direito de influir no destino do mundo, jamais fará arte paranista, no mau sentido da palavra. Ela fará simplesmente arte".49 El adjetivo "paranista" (que servía a Trevisan para caracterizar lo reaccionario) era derribado uniendo la provincia con el mundo. Un arte no delimitado por adjetivos de esta naturaleza fue el proyecto de esta generación internacionalista. ${ }^{\circ}$

Respecto de los compromisos políticos, resulta evidente el interés mutuo de Joaquim y de la AACI por la definición de un nuevo tipo de hombre universal y por la responsabilidad con los acontecimientos mundiales. Sin embargo, la diferencia más radical entre ambos grupos remitía precisamente a los posicionamientos estéticos e ideológicos. Joaquim no se presentó como una revista marxista más allá de las

46 SANCHEZ NETO, Miguel. Joaquim: modernidade periférica e dupla ruptura. Op. cit.

47 TREVISAN, Dalton. A geração dos vinte anos na ilha. Joaquim, nº 9, Curitiba, marzo de I947, p. 3.

48 Idem, ibidem.

49 Idem, ibidem.

50 SANCHEZ NETO, Miguel. Joaquim: modernidade periférica e dupla ruptura. Op. cit. 
vinculaciones que muchos de sus colaboradores mantenían con el PC brasileño. Joaquim optó por una actitud tan pluralista que, como se analizó, publicó manifiestos de diversas tendencias y aceptó colaboraciones hasta contrapuestas. De hecho, en relación con las conexiones argentinas, no sólo publicaban las propuestas de la AACI, sino que también aparecía en el último número de Joaquim Héctor P. Agosti y su "Defesa do Realismo". ${ }^{\text {I }}$ Cerrando el círculo de intercambios entre publicaciones, este artículo había aparecido anteriormente en Contrapunto. ${ }^{2}$

Las divergencias entre la AACI y los jóvenes de Joaquim eran totalmente evidentes; sin embargo, artistas y poetas siguieron reconociéndose mutuamente como aliados por la causa moderna. De hecho volverían a encontrarse en las páginas de Joaquim en una polémica contra un manifiesto enemigo común: José Bento Monteiro Lobato.

\section{Monteiro Lobato entre Argentina y Brasil}

Dos décadas después del famoso ataque de Monteiro Lobato a Anita Malfatti, el escritor actuaba nuevamente como la contrafigura aglutinadora que unía artistas y poetas que luchaban por lo nuevo. Asimismo, Monteiro Lobato ya había colaborado como figura de contraposición en anteriores vinculaciones entre argentinos y brasileños: Patricia M. Artundo ha señalado el interés de Mário de Andrade al encontrar en las revistas Los Pensadores y Martín Fierro otro núcleo de relaciones argentinas..$^{33}$ Estos vínculos diferían explícitamente de la conocida amistad entre Cesáreo B. de Quirós y Lobato: ambos representaban la construcción de un nacionalismo positivista que no resultaba en nada atractivo para este escritor modernista.54

En Joaquim el primer ataque a Lobato apareció en el número doce conducido por Dalton Trevisan, en el momento que se publicaba la obra completa de este escritor. ${ }^{55}$ Como en las otras polémicas, la marca de juventud guiaba al articulista cuando manifestaba su intolerancia hacia las posturas reaccionarias. Para Trevisan, Monteiro Lobato se había traicionado a sí mismo y a su tiempo no sólo por no haber comprendido la renovación artística de I922, sino también por no querer divisar a la juventud: "Esteve contra o modernismo, como esteve contra todos os movimientos de renovação de nossa arte; em literatura pintou as mesmas dálias e tachos de um mundo morto. Jamais quis participar de seu tempo e, por isso, traí-0"56. Al final de este artículo, Dalton revelaba la razón de su furia contra el autor de Urupês: "Quando um repórter lhe disse que os moços viam nele, por causa de sua prisão na ditadura, um

5 I AGOSTI, Héctor P. Defesa do Realismo. Joaquim, nº 2I, Curitiba, diciembre de I948, p. I6. 52 AGOSTI, Héctor P. Defensa del Realismo. Contrapunto, $\mathrm{n}^{\circ}$ 3, Buenos Aires, abril de I945, p. 5.

53 ARTUNDO, Patricia M. Mário de Andrade e a Argentina... Op. cit.

54 Idem, ibidem.

55 TREVISAN, Dalton. O terceiro indianismo. Joaquim, ${ }^{\circ}$ I2, Curitiba, agosto de I947, p. I2.

56 Idem, ibidem. 
'exemplo de resistência', respondeu com tais palavras: 'Não acredito nesses moços...' E desta vez, como das outras, o Sr. Monteiro Lobato se enganou tragicamente”57.

Trevisan centró sus críticas en Urupês declarándolo un libro ilegible; le reprochaba no haber logrado una investigación moderna sobre la vida cabocla (mestizaje indígena) optando por un lenguaje artificialmente estilizado y valiéndose de una sintaxis lusitana que tenía a la vida brasileña sólo como tema. Risueñamente Trevisan aludía al exilio de Lobato en la Argentina: "nas horas de grave perigo no país, despedindo-se do Jeca para ir engordar com suculentos bifes na Argentina" 58 .

En Joaquim, dos números más tarde de la afrenta de Trevisan, un argentino, el artista concreto Raúl Lozza volvía a la carga con la "Carta aberta a Monteiro Lobato" 59 . Ésta ya había aparecido en diciembre de 1946 en la segunda publicación de la AACI: el Boletín de la Asociación Arte Concreto-Invención. ${ }^{60}$ El detonante para la aparición de la "Carta abierta a Monteiro Lobato" de Lozza había sido el artículo "Un nuevo Stalingrado: Quirós” publicado por el escritor brasileño en el diario El Mundo en noviembre de I946. ${ }^{6 \mathrm{I}}$ Esta crítica, aparecida en ocasión de la exposición de Cesáreo Bernaldo de Quirós en la Galería Witcomb, se proponía como un ajuste de cuentas con la crítica de arte que Lobato consideraba tendenciosa y responsable del silencio sobre la obra del pintor entrerriano. La virulencia de su tono contra el arte moderno y las metáforas y asociaciones que utilizaba para su caracterización la constituía en una nueva punta de lanza con la cual Lobato volvía a enfrentarse con las propuestas renovadoras. Para el brasileño, el pintor entrerriano era una víctima del arte moderno, de sus artistas y sus críticos para los cuales "la grandeza ya no era entonces la de los titanes de la pintura, sino la de Picasso y otros productos de la mistificación dominante." ${ }^{2}$ Sin embargo, Lobato no se limitaba a ser un detractor del arte moderno sino que iba aún más lejos estableciendo un peligroso paralelismo con el nazismo:

El fenómeno artístico denominado "modernismo", consistente en el repudio a todas las normas estéticas del pasado, parece ser un simple reflejo, o trasplante en otro plano, del fenómeno político nazismo, consistente en el repudio a todas las normas morales. El nazismo disponía de la Gestapo para imponer sus dogmas por la violencia, y el modernismo se enseñoreó de la crítica de arte del mundo entero para imponer sus teorías. Y la situación de la conciencia artística en los países dominados por esta crítica sectaria se aproximó mucho a la situación de la conciencia moral de los pueblos

57 Idem,ibidem.

58 TREVISAN, Dalton. O terceiro indianismo.... Op. cit.

59 LOZZA, Raúl, Carta aberta a Monteiro Lobato. Joaquim, nº I4, Curitiba, octubre de I947, p. 3.

60 LOZZA, Raúl, Carta abierta a M. Lobato. Boletín de la Asociación Arte Concreto-Invención, $\mathrm{n}^{\circ}$ 2, Buenos Aires, diciembre de I946, p. 5 .

6I MONTEIRO LOBATO, José. Un nuevo Stalingrado:... Op. cit.

62 Idem, ibidem. 
dominados por la Gestapo. [...] El caso de Bernaldo de Quirós es el Stalingrado del nazismo pictórico modernista. ${ }^{63}$

Para Lobato la exposición era casi una lección que permitiría a los jóvenes artistas "que se alistaron entre los modernistas del mismo modo que, llevados por el terror, tantos jóvenes alemanes se alistaron en las huestes de Hitler"- desprenderse de estas ataduras y entregarse al "gran arte verdadero y eterno". ${ }^{64}$ Quirós representaba para la historia del arte al igual que Stalingrado para la historia de la Segunda Guerra, el inicio de la victoria sobre las fuerzas destructivas.

Las asociaciones que proponía la crítica de Lobato resultaban inadmisibles. Así fue que Raúl Lozza militante del PC desde I933 y totalmente comprometido con los acontecimientos del conflicto bélico reaccionó escribiendo y publicando en distintos medios su carta abierta. Lozza disentía rotundamente del planteo de Lobato. Por un lado, el artista concreto marcaba que en los países donde imperó el nazismo y el fascismo, todo el arte moderno, especialmente el más avanzado había sido perseguido despiadadamente; a su vez, señalaba que los artistas más modernos del mundo hacían sus esfuerzos a favor de la causa progresista. En este sentido, Lozza apuntaba a la irresponsabilidad y superficialidad de la crítica de Lobato: "Mal ha señalado Ud. el ejemplo de Stalingrado. Adquiere un contenido muy extraño y confuso en sus labios" 65 .

Por otro lado, Lozza descalificaba la pintura de Quirós: "El BUEN GUSTO, el arte de una casta desplazada históricamente no puede constituir la manifestación espiritual viva de un pueblo." ${ }^{66}$ Quirós, representante de un naturalismo folclórico, era leído en los años I940 como la imagen de la ideología nacionalista y, por ende, su obra significaba para Lozza la "máxima expresión de retornismo". Además, recuérdese que Quirós se desempeñaría a partir de I949 como vocal de la Comisión Nacional de Cultura del gobierno peronista; esta alineación estético-política era antitética respecto de una lectura moderna del campo cultural. Refiriéndose a los datos que Lobato proporcionaba en su nota sobre la vida de Quirós, Lozza condensaba los perfiles de los detractores del arte moderno en una risueña metáfora: “Hay una sutil - pero evidente relación entre una estancia a orillas del Paraná, una beatífica meditación de 'CINCO AÑOS', un fracasado aventurero de las letras, como Lazcano (sic.) Tegui (...), la pintura oficialista y el churrasco jugoso"67.

Evidentemente, en la visión de este artista concreto, Lobato y Quirós representaban las mismas posiciones imbricadas tanto en el campo estético como en el ambiente político. La estancia de Quirós en Entre Ríos, su pintura de gauchos y el retiro reflexivo; asimismo la extravagancia y frivolidad de la pluma de Lascano

\footnotetext{
63 Idem, ibidem.

64 MONTEIRO LOBATO, José. Un nuevo Stalingrado: Quirós. El Mundo, Buenos Aires, I de noviembre de I946, p. 4, I4.

65 LOZZA, Raúl. Carta abierta a M. Lobato. Op. cit.

66 Idem, ibidem.

67 Idem, ibidem. Mayúsculas en el original.
} 
Tegui quien había escrito una descalificadora crítica sobre la exposición de los concretos en el Salón Peuser , el nacionalismo de Lobato y, sin duda, el gusto por la buena carne armaban un conjunto que caracterizaba aquello a lo que se oponían los jóvenes invencionistas. Esta selección representaba lo nacional en sus expresiones más xenófobas y lo artístico en tanto conservadurismo, elementos que podían vincularse a elecciones que también describían la política cultural peronista.

Este gobierno mucho tenía que ver con el exilio de Lobato en Buenos Aires. La recepción fue muy acogedora: en junio de 1946 diarios y revistas anunciaban calurosamente la llegada del escritor brasileño. Por su parte, las autoridades del gobierno peronista lo exhibieron como un valioso trofeo de la causa de la integración americana. ${ }^{68}$ En cuanto a su producción, en el periodo que vivió en Buenos Aires, se lanzaron veintitrés títulos de sus libros infantiles por la editorial Américalee y fundó la editorial Acteon. Además, fue objeto de la "Semana Monteiro Lobato" patrocinada por la casa Harrod's y se constituyó en el principal animador de la Exposición del Libro Brasileño que organizó la Embajada.69

Bajo el pseudónimo de Manuel P. García, Monteiro Lobato fue quien hizo accesible a los niños las principales líneas de la política peronista. La Nueva Argentina libro editado por su editorial Acteón fundada con aportes argentinos y brasileños estaba escrita a la manera de un cuento: los diálogos entre dos niños y su padre conformaban la estructura narrativa. El argumento versaba sobre distintos aspectos de la alternativa peronista como política social de paz, desarrollo y equidad. El padre, totalmente comprometido con el gobierno, contestaba las preguntas que los chicos le hacían sobre la situación del país. Él les explicaba aspectos de la explotación de los recursos naturales, cuestiones de rentabilidad económica, proyectos para la educación, la ciencia y la salud. En una oda de halagos al gobierno, el personaje del padre exponía las propuestas que, para todos estos temas, tenía el Plan Perón. El libro, instrumento de propaganda oficial, afirmaba rotundamente la supremacía argentina en América del Sur en función de su nuevo programa político.

La ilustración de la tapa interpretaba exactamente la atmósfera que planteaba el libro. La representación de una familia de espaldas, con su perro, que contemplaba la nueva Argentina: tanto en el campo - con grandes plantaciones- como en la ciudad con industrias, aviones y autopistas el país crecía gracias al Plan. Según ha señalado Marcela Gené, la familia era, para el aparato de representación visual peronista, la imagen condensadora de la totalidad social, logrando expresar con mayor eficacia el progreso material, el acceso al consumo y el ostensible aumento de la calidad de vida de los sectores populares..$^{70}$ Efectivamente, el libro de Lobato participaba de la construcción de este "mundo feliz" de la primera etapa del gobierno peronista en el cual la bonanza del comercio exterior había permitido el desarrollo del pleno empleo, el aumento de los salarios y un profundo cambio distributivo.

68 JOFFRE BARROSO, Haydée M. Monteiro Lobato. Un escritor, un país. Buenos Aires: Galerna, 2000, p. I50-I5I.

69 Idem, ibidem..; SORÁ, Gustavo. Traducir el Brasil. Op. cit., p. I47.

70 GENÉ, Marcela. Un mundo feliz. Imágenes de los trabajadores en el primer peronismo I946-I955. Buenos Aires: Fondo de Cultura, 2005, p. I3-23. 


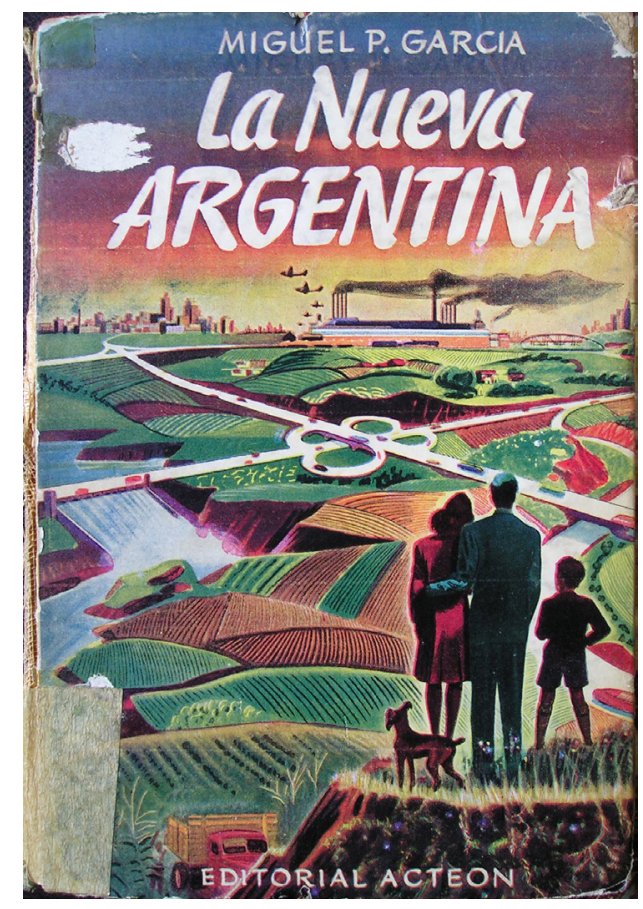

Ilustración 6. Manuel P. García [seud. Monteiro Lobato], La Nueva Argentina, Buenos Aires, Acteon, I947.

Al escribir La Nueva Argentina, Monteiro Lobato se encontraba entregado a la construcción política peronista pero, al margen de sus simpatías con este gobierno, llama la atención el enfoque sesgado de sus afirmaciones en el contexto de posguerra. Objetivamente parecía ser Brasil y no la Argentina el que se perfilaba como el nuevo detentor de la hegemonía regional. Buenos Aires, en tanto poseedora de la cultura ilustrada en la región no tuvo competencia hasta la Segunda Guerra Mundial cuando la situación fue considerablemente revertida. Si el escenario político-cultural mundial se reconfiguró totalmente, el panorama sudamericano tampoco quedó indemne. En este sentido, los diferentes posicionamientos de la Argentina y de Brasil respecto del conflicto bélico trajeron no sólo consecuencias político-económicas sino también efectos sobre las prácticas culturales.

Desde finales de los años I940 el Brasil puso en funcionamiento una compleja maquinaria de gestión cultural buscando convertirse en un punto clave en el mundo de las artes. Entre I947-I949 en São Paulo y en Rio de Janeiro se abrieron tres museos de arte que reconfiguraron no sólo la escena artística brasileña, sino también el panorama regional y a su vez, a partir de I95I, la Bienal paulista aspiraba diseñar 
una nueva geografía para el mundo de las artes. Además, este evento ubicaba a Brasil definiendo su hegemonía cultural, política y económica en el ámbito sudamericano. ${ }^{7 \mathrm{I}}$

Esta investigación ha analizado el rol clave que cumplieron las revistas culturales en la vehiculización de las interrelaciones entre los artistas argentinos y brasileños durante los años I940. A partir del comienzo de la nueva década, las instituciones brasileñas se convirtieron en el eje articulador de estos intercambios. Los artistas argentinos comenzaron a intervenir activamente en el circuito de los museos brasileños: piénsese, por ejemplo, en la exposición del Grupo de Artistas Modernos en el MAM-RJ en I953 y en la representación argentina en la II Bienal. Además, críticos como Romero Brest quien se desempeñó como jurado en varias bienales paulistas consiguió constituirse en un valor de referencia para el ámbito artístico vecino. Durante los años I960 las instituciones continuaron detentando un rol desatacado en las interrelaciones culturales entre ambos países, como en el caso de las interacciones entre los miembros de los grupos "Nueva Figuración” y "Nova Objetividade” a través de exposiciones en la galería Bonino y en el MAM de Rio de Janeiro.72

En suma, revistas y exhibiciones materializaron la inscripción de las tendencias vanguardistas y los procesos de comunicación e intercambio creativo entre artistas argentinos y brasileños. Si bien ambos soportes se constituyeron en vehículos privilegiados de las relaciones culturales, es posible afirmar que durante los años I950 y I960 el dispositivo de exhibición adquirió mayor relevancia en línea con el surgimiento y consolidación de un sistema institucionalizado de internacionalización de las artes. Así, "vanguardia en doble página" marca un momento particular de circulación del arte moderno y su proyecto.

7I HERKENHOFF, Paulo. A Bienal de São Paulo e seus compromissos culturais e políticos. Revista USP, $\mathrm{n}^{\circ}$ 52, São Paulo, 200I-2002, p. II8-I2I; FRANÇA LOURENÇO. Maria Cecília, Museus acolhem moderno. São Paulo: EDUSP, I999; AMARAL, Aracy. Museu de Arte Contemporânea da Universidade de São Paulo, Perfil de um Acervo, São Paulo: Techint, I986; TEIXEIRA DE BARROS, Regina. Revisão de uma história: a criação do Museu de Arte Moderna de São Paulo I946-I949, Tesis de Maestria, Universidade de São Paulo, São Paulo, 2002, mimeo.

72 HERKENHOFF, Paulo. Nova Figuração Rio/Buenos Aires, Rio de Janeiro: Galeria do Instituto Cultural Brasil-Argentina, I987; republicado en Jorge de la Vega. Obras I96I-I97I, Buenos Aires: Malba, 2003, p. 3I-36; GIUNTA, Andrea, Hacia las 'nuevas fronteras': Bonino entre Buenos Aires, Rio de Janeiro y Nueva York, IN: VV.AA.. El arte entre lo público y lo privado. Buenos Aires: CAIA, I995, p. 277-284. 


\section{SOBRE A AUTORA}

MARÍA AMALIA GARCía es doctora de la Universidad de Buenos Aires en el área Historia y Teoría del Arte, licenciada en Artes por la misma casa de estudios y profesora nacional de pintura de la Escuela Nacional de Bellas Artes "Prilidiano Pueyrredón”, IUNA. Es investigadora de CONICET, docente en la Carrera de Artes (FFyL-UBA) y en la Maestría en Curaduría en Artes Visuales (UNTREF)

E-mail: mamaliag@gmail.com

\section{REFERÊNCIAS BIBLIOGRÁFICAS}

AGOSTI, Héctor P. Defensa del Realismo. Contrapunto, $\mathrm{n}^{\circ}$ 3, Buenos Aires, abril de 1945. . Defesa do Realismo. Joaquim, $\mathrm{n}^{\circ} 2 \mathrm{I}$, Curitiba, diciembre de 1948.

AMARAL, Aracy. Arte para quê? A preocupação social na arte brasileira I930-I970. São Paulo, Nobel, 2003. . Museu de Arte Contemporânea da Universidade de São Paulo, Perfil de um Acervo, São Paulo, Techint, I986.

ANTELO, Raúl. Coleccionismo y modernidad: Marques Rebêlo, marchand d'art. IN: Epílogos y prólogos para un fin de siglo. VIII Jornadas de Teoría e Historia de las Artes. Buenos Aires, CAIA, I999. . Confluencia. Literatura argentina por brasileños. Literatura brasileña por argentinos. Buenos Aires, Centro de Estudos Brasileiros, I982.

ARTUNDO, Patricia M. Mário de Andrade e a Argentina: um pais e sua produção cultural como espaço de reflexão. São Paulo: EDUSP-FAPESP, 2004. . (org.). Correspondência Mário De Andrade e Escritores / Artistas Argentinos. São Paulo, EDUSP-IEB, 2013.

BAJARLÍA, Juan Jacobo. Literatura de vanguardia. Del “Ulises" de Joyce a las escuelas poéticas. Buenos Aires, Araujo, I946.

.Carta a Carlos Drummond de Andrade, Buenos Aires, 5 de marzo de I947. CDA-CP- I66. Biblioteca-Arquivo de Literatura Brasileira "Casa Rui Barbosa”, Rio de Janeiro.

.Carta a Carlos Drummond de Andrade, Buenos Aires, I6 de marzo de I948. CDA-CP- I66. Biblioteca-Arquivo de Literatura Brasileira “Casa Rui Barbosa”, Rio de Janeiro.

.Carta a Carlos Drummond de Andrade, Buenos Aires, 4 de agosto de I948. CDA-CP- I66. Biblioteca-Arquivo de Literatura Brasileira “Casa Rui Barbosa”, Rio de Janeiro.

.Carta a Carlos Drummond de Andrade, Buenos Aires, 24 de enero de I949. CDA-CP-I66. Biblioteca-Arquivo de Literatura Brasileira “Casa Rui Barbosa”, Rio de Janeiro

BAYLEY, Edgar et al. Manifiesto Invencionista. Joaquim, nº 9, Curitiba, marzo de I947, p. I2. 
.Manifiesto Invencionista. $I^{a}$ Exposición de la Asociación Arte concreto-invención, Buenos Aires, Salón Peuser, I8 de marzo al 3 de abril de I946.

BRUGHETTI, Romualdo. Un mundo más puro y sencillo. El arte abstracto en la Argentina. Cabalgata, $\mathrm{n}^{\circ} 4$, Buenos Aires, I9 de noviembre de I946.

CAMPOFIORITO Quirino. Os ilustradores de Joaquim. Joaquim, $\mathrm{n}^{\circ}$ Io, Curitiba.

DE MAISTRE, Agnès. Les groupes Arte Concreto-Invención et Madí. IN: Art d'Amérique Latine I9III968. Paris: Musée National d’Art Moderne. Centre Georges Pompidou, I992.

DRUMMOND DE ANDRADE, Carlos. Invencionismo. Correio da Manhã, Rio de Janeiro, I de diciembre de I946, seção 2, p. I.

.Invencionismo. Joaquim, $\mathrm{n}^{\circ}$ 9, Curitiba, marzo de I947, p. I3.

. Mundo Mayor. Contrapunto, $\mathrm{n}^{\circ}$ 5, Buenos Aires, agosto de I945.

.El enigma. Caballo de Fuego, año IV, $n^{\circ}$ 6, Buenos Aires, I950, p. 5.

ESTARICO, Leonardo. Veinte pintores brasileños. Contrapunto, $n^{\circ} 6$, Buenos Aires, octubre de I945.

FRANÇA LOURENÇO. Maria Cecília, Museus acolhem moderno. São Paulo, EDUSP, I999.

FREITAS, Artur. A consolidação do moderno na história da arte do Paraná: anos 50 e 6o. Revista de História Regional, ${ }^{\circ}$ 8, Invierno 2003.

GARCÍA, María Amalia. El arte abstracto. Intercambios culturales entre Argentina y Brasil. Buenos Aires, Siglo XXI, $20 I I$.

GENÉ, Marcela. Un mundo feliz. Imágenes de los trabajadores en el primer peronismo I946-I955. Buenos Aires, Fondo de Cultura, 2005

GIUNTA, Andrea, Hacia las 'nuevas fronteras': Bonino entre Buenos Aires, Rio de Janeiro y Nueva York, IN: VV.AA.. El arte entre lo público y lo privado. Buenos Aires, CAIA, I995.

HERKENHOFF, Paulo. A Bienal de São Paulo e seus compromissos culturais e políticos. Revista USP, $\mathrm{n}^{0}$ 52, São Paulo, 200I-2002.

.Nova Figuração Rio/Buenos Aires, Rio de Janeiro: Galeria do Instituto Cultural Brasil-Argentina, I987; republicado en Jorge de la Vega. Obras I96I-I97I, Buenos Aires, Malba, 2003.

JOFFRE BARROSO, Haydée M. Monteiro Lobato. Un escritor, un país. Buenos Aires, Galerna, 2000.

LIMA, Jorge de. Lámpara Marina. Contrapunto, $\mathrm{n}^{\circ}$ 5, Buenos Aires, agosto de 1945.

LOZZA, Raúl. Carta abierta a M. Lobato. Boletín de la Asociación Arte Concreto-Invención, $\mathrm{n}^{\circ}$ 2, Buenos Aires, diciembre de I946.

.Carta aberta a Monteiro Lobato. Joaquim, $\mathrm{n}^{\circ}$ I4, Curitiba, octubre de 1947.

MALDONADO, Tomás. Vanguardia y racionalidad. Barcelona, Gustavo Gili, I977.

MARQUES REBÊLO. Carta a Carlos Drummond de Andrade, Buenos Aires, 9 de julio de I945, CDACP- I45I, Biblioteca-Arquivo de Literatura Brasileira "Casa Rui Barbosa”, Rio de Janeiro. .Carta a Carlos Drummond de Andrade, Rosario, I4 de septiembre de I945, CDA-CP- I45I, Biblioteca-Arquivo de Literatura Brasileira "Casa Rui Barbosa”, Rio de Janeiro.

.Carta a Calos Drummond de Andreade, Buenos Aires, 3 de mayo de I945, CDA-CP- I45I, Biblioteca-Arquivo de Literatura Brasileira "Casa Rui Barbosa”, Rio de Janeiro.

MARTINS, Luis. La pintura brasileña contemporánea. O Estado de São Paulo, 4 de marzo de I946, caja I sobre 5, documento I07 Archivo Jorge Romero Brest, FFyL-UBA.

MILLIET, Sergio. Carta a Jorge Romero Brest, São Paulo, 6 de mayo de I946, documento 362, Archivo Jorge Romero Brest, FFyL-UBA.

MONTEIRO LOBATO, José. Un nuevo Stalingrado: Quirós. El Mundo, Buenos Aires, I de noviembre de 1946. 
NAVARRA, Rubens. Um livro sobre a pintura brasileira. Diário de Noticias, s/d, I946, caja I sobre 5, documento Io6A, Archivo Jorge Romero Brest, FFyL-UBA.

PERAZZO, Nelly. El Arte Concreto en la Argentina. Buenos Aires, Gaglianone, I983.

PÉREZ-BARREIRO, Gabriel (cur.). The Geometry of Hope. Latin American Abstract Art from the Patricia Phelps de Cisneros Collection. Austin: The Blanton Museum-University of Texas at Austin, 2007.

ROMERO BREST, Jorge. La pintura brasileña contemporánea. Buenos Aires, Poseidón, I945.

ROSSI, Cristina. Las utopías constructivas en la posguerra rioplatense. Tesis de doctorado, Facultad de Filosofía y Letras, UBA, 20Io, mimeo.

S/a [PAYRÓ, Julio E.] La caída del marco. Qué sucedió en 7 días, Buenos Aires, I5 de agosto de 1946.

S/a Arte Concreto. La Nación, Buenos Aires, 20 de marzo de I946, p.4.

S/a Exposición de Arte Concreto. La Prensa, Buenos Aires, 23 de marzo de I946, p. 9.

SANCHEZ NETO, Miguel. Joaquim: modernidade periférica e dupla ruptura. IN: SCHWARTZ, Jorge y PATIÑO, Roxana, Revista Iberoamericana: Revistas literarias/culturales latinoamericanas del siglo XX, $\mathrm{n}^{0}$ 208-209, Pittsburgh University, 2004.

SOARES DE OLIVERA, Luiz Cláudio. Joaquim contra o Paranismo. Tesis de Maestria, Universidade Federal do Paraná, Curitiba, 2005.

SORÁ, Gustavo. Traducir el Brasil. Una antropología de la circulación de ideas. Buenos Aires: Del Zorzal, 2003.

TEIXEIRA DE BARROS, Regina. Revisão de uma história: a criação do Museu de Arte Moderna de São Paulo I946-I949, Tesis de Maestria, Universidade de São Paulo, São Paulo, 2002, mimeo.

TREVISAN, Dalton. A geração dos vinte anos na ilha. Joaquim, $n^{\circ} 9$, Curitiba, marzo de I947. .Emiliano, poeta mediocre. Joaquim, $\mathrm{n}^{\circ}$ 2, Curitiba, junio de 1946. .O terceiro indianismo. Joaquim, $\mathrm{n}^{\circ} \mathrm{I2}$, Curitiba, agosto de 1947.

V. de L. T. [LASCANO TEGUI, Vizconde de]. Modernos y pasatistas. El Mundo, Buenos Aires, 6 de abril de I946. 